\title{
Digital planet: How smart technologies can help us solve our climate and infrastructure challenges
}

Written by: Zoe Lagarde, OECD Environment Directorate

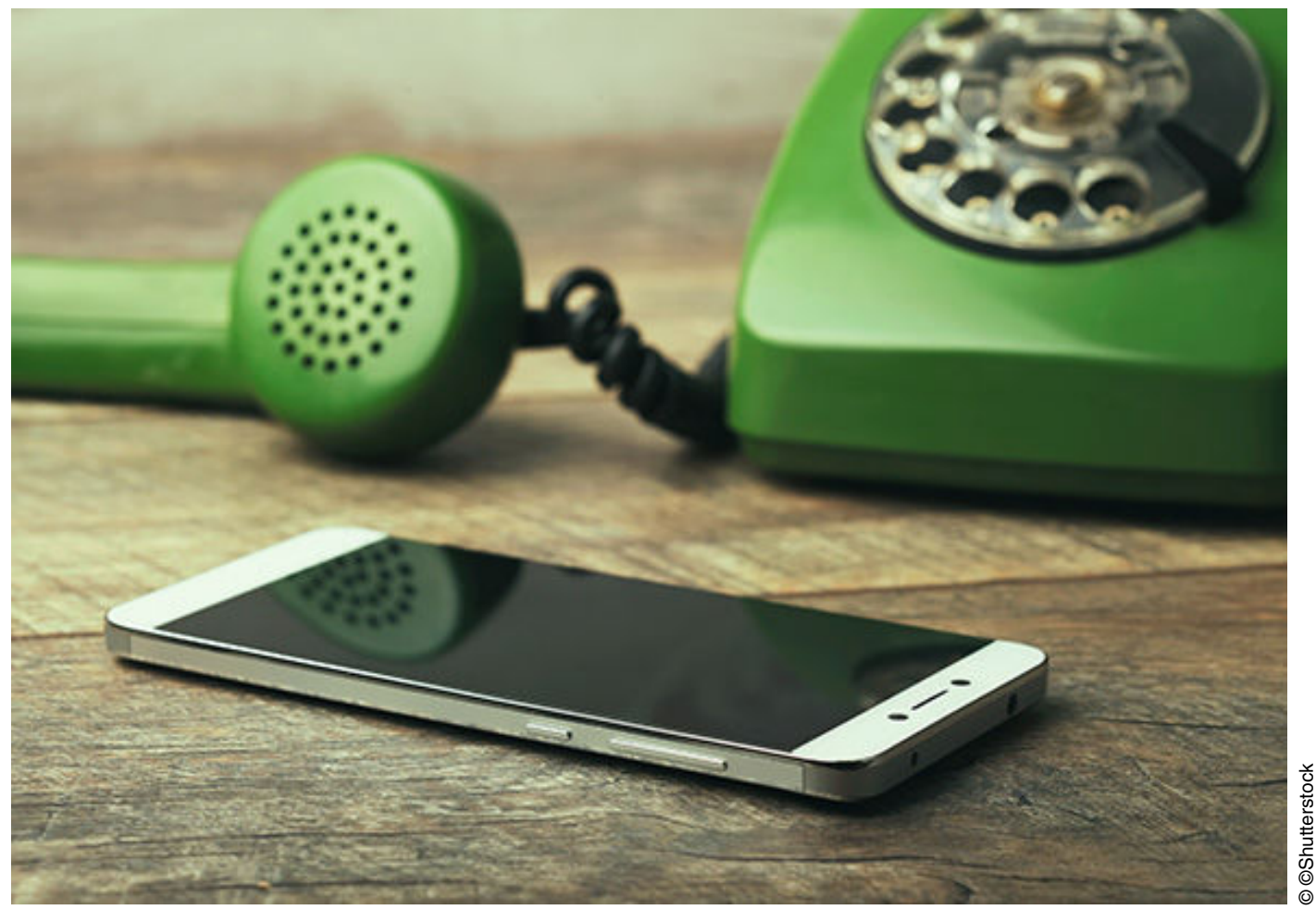

Digital planet: How smart technologies can help us solve our climate and infrastructure challenges

Back in the 1960s, when my dad wanted to make an international call for work, he had to order it $\mathbf{2 4}$ hours in advance. Today, he uses WhatsApp to make toll-free calls from anywhere, anytime, in just a couple of clicks.

When we think about innovation we often think about grand inventions, such as space ships to colonise other galaxies, or indeed, mobile phone apps. But too often we forget to notice innovation where it impacts us directly and tremendously: in 
the simple things of our everyday lives. Such as the way we pay for stuff, or what we also call "digital finance".

Digital finance refers to the way digital technologies, such as smart phones, online platforms, bitcoins and blockchain, can be used to manage, save, distribute and spend money. Over the past years, new technologies and software have emerged making it easier for people to make payments (think PayPal), or to raise crowd-fund money for projects (think GoFundMe).

Great. But, what does this have to do with sustainability, you may be thinking?

At the heart of sustainability lies the question of infrastructure and related investments. Infrastructure covers everything from roads and rail to power grids, water supply and phone antennas. All together it is responsible for $60 \%$ of global greenhouse gas emissions. That's a colossal amount, and given the long-life spans of most infrastructure assets, many of these emissions won't go away soon.

Yet, infrastructure investments have been historically low for years, and with the rapid growth of both emerging and developing economies, there is a huge investment gap that calls to be filled.

If the right decisions are taken, this gap could be addressed smartly and cleanly, especially, if new technologies, such as digital finance, are brought into play. Digital finance and digitilisation are already driving forward climate action, through the emergence of new business models, for example 'pay-as-you-go' for using decentralised solar devices in rural communities. They have unlocked new sources of finance, such as matching for investors and project owners. They are offering a wider range of sustainable choices and options for consumers, such as saving energy thanks to smart meters and real-time pricing for instance. This can give real hope to sustainability projects, which traditional banks had tended to avoid because of high costs and long payback periods. But now the technology has improved, as has the potential of clean infrastructure to meet people's demands.

Take, for example, institutional investors, such as banks, insurers and pension funds that hold trillions of dollars in infrastructure assets under management. Many of them are willing to fund more climate projects, and the money is there. But too often, because of the fragmented nature of the sector, these investors do not have enough information on existing projects that would meet their environmental criteria. This is a huge missed opportunity, which some are trying to address through digital tools that provide environmental evaluations of infrastructure assets. For example, GRESB Infrastructure is an initiative that develops environmental, social and governance scorecards and benchmark reports on infrastructure assets. It uses sophisticated IT tools to crunch data set indicators, such as energy consumption, GHG emissions, water consumption and waste. It currently brings together 75 investors that represent over US\$18 trillion in institutional capital, and its activities to address material issues affecting sustainability projects, continue to grow. This is also not a standalone example,

2 www.oecdobserver.org I Digital planet: How smart technologies can help us solve our climate and infrastructure challenges 
and many other efforts are underway to provide better data to financiers, to enhance project transparency and accountability, and to help shift those trillions of dollars towards low-emission infrastructure investments.

But there are questions to be answered over the true environmental and economic benefits of these new technologies. For instance, will blockchain and cryptocurrency help us save energy, or will they consume more of it? What about cyber attacks and potential costly economic disruptions they cause? In short, being connected means that policymakers have to be mindful of systemic risks, and issues such as data privacy.

That is why good monitoring and evaluation, with fact-based analysis, of the kind we at the OECD conduct, is so important. Technology and innovation may shape our lives and our climate efforts in ways we could have never imagined before, but with clear vision we can avoid new forms of inertia, stoking up vested interests, or repeating mistakes of the past.

Can we be smart enough to succeed in this? I believe we can. Digital finance and new technologies are full of promise, but to realise their potential, policymakers and policy shapers must remain agile in pursuit of better environmental policies for better lives. After all, who knows, in 40 years, our smartphones may be as out of date as my father's old phone in the 1960s!

COECD Observer No 317 Q1 2019

\section{References}

For more information on the Financing Climate Futures initiative and case studies, see: http://www.oecd.org/environment/cc/climate-futures/

http://www.oecd.org/environment/cc/climate-futures/case-study-digitalfinance-and-citizen-action.pdf http://www.oecd.org/environment/cc/climatefutures/case-study-digital-finance-and-citizen-action.pdf

http://www.oecd.org/environment/cc/climate-futures/case-study-achievingclean-energy-access-in-sub-saharan-africa.pdf http://www.oecd.org/ environment/cc/climate-futures/case-study-achieving-clean-energy-access-insub-saharan-africa.pdf 